\title{
手術支援機器による術中判断と行動
}

\author{
村垣 善浩1)2)，伊関 洋1)2)，丸山 隆志12)，新田 雅之 ${ }^{1) 2}$ ，齋藤 太—2)，田村 学122)， \\ 都築 俊介 ${ }^{2)}$, 安田 崇之 ${ }^{2)}$, 岡田 芳和 ${ }^{2)}$, 川俣 貴一2) \\ 1）東京女子医科大学先端生命医科学研究所先端工学外科分野，2）同 脳神経外科
}

\section{Intraoperative Judgments and Actions based on Diagnostic Surgical Devices}

\author{
Yoshihiro Muragaki, M.D. ${ }^{1) 2}$, Hiroshi Iseki, M.D. ${ }^{1) 2}$, Takashi Maruyama, M.D. ${ }^{12)}$, \\ Masayuki Nitta, M.D. ${ }^{1)}$ ) , Taiichi Saito, M.D. ${ }^{2)}$, Manabu Tamura, M.D. ${ }^{12)}$, Shunsuke Tsuzuki, M.D. ${ }^{2)}$, \\ Takayuki Yasuda, M.D. ${ }^{2}$, Yoshikazu Okada, M.D. ${ }^{2)}$, and Takakazu Kawamata, M.D. ${ }^{2}$ \\ 1) Faculty of Advanced Techno-Surgery (FATS), Institute of Advanced Biomedical Engineering \& Science, Graduate \\ School of Medicine, Tokyo Women’s Medical University, 2) Depertment of Neurosurgery, Tokyo Women’s Medical Univer- \\ sity
}

Surgeons continue attempts to improve treatment results with development of the individual skills and intraoperative techniques in a continuous life-long fashion. Nevertheless, a dramatic change in medical practice had happened with introduction of the novel medical technologies for advanced diagnostics and treatment, such as computed tomography, magnetic resonance imaging, stereotactic radiosurgery, endovascular coils, surgical microscope, intraoperative navigation systems, etc. The present article highlights the impact of the diagnostic surgical devices on the intraoperative judgements and actions.

The main purpose of the diagnostic surgical devices is intraoperative visualization of the biological signals. The first step of this process, visualization itself, already contributes to clinical decision-making, but obtained information is qualitative, thus experience is required for its precise interpretation. The second step is regarded to transformation of the subjective qualitative information into objective quantitative digital data using various image analyzers and/or computer software. During the third step the quantitative digital data are converted into objective anatomical, functional, and histopathological information, which can be used for scientifically-based intraoperative decision-making, taking into consideration the thresholds of resection rate, stimulation current, malignancy index of the tissue specimen, etc.

Since all these thresholds provide not absolute recommendations, but possible guidelines for surgical actions, the information used for intraoperative decision-making should consider the details of the individual case and include probabilistic statistical analysis based on the feedback from the multicenter databases. Development of such comprehensive support system for intraoperative decision-making carries significant potential to improve surgical results in the future.

(Received February 18, 2016; accepted March 23, 2016)

Key words : surgical device, decision-making, information

Jpn J Neurosurg（Tokyo） $25: 555-565,2016$

連絡先：村垣善浩， $=162-8666$ 新宿区河田町 8-1 東京女子医科大学先端生命医科学研究所先端工学外科分野

Address reprint requests to: Yoshihiro Muragaki, M.D., Faculty of Advanced Techno-Surgery, Institute of Advanced Biomedical Engineering \& Science, Graduate School of Medicine, Tokyo Women's Medical University, 8-1 Kawada-cho, Shinjuku-ku, Tokyo 162-8666, Japan 


\section{はじめに}

手術は道具や技術とともに進化してきた。メスや針 糸, その後吸引器や電気凝固等の道具の開発, 消毒や滅 菌そして麻酔等の基盤技術の開発によって近代手術の基 本型が確立した。そして，顕微鏡や内視鏡等により治療 部位を前者は微細に, 後者は別角度あるいは内腔から観 察することで, 患者への低侵襲手術が確立した。次に, 特に頭頝部外科領域から CT あるいは MRI 等の術前術中 画像を用いたナビゲーション等による情報誘導手術が始 まっている。

手術支援機器によってもたらされるこれらの大きな変 化は, 非連続的であり導入当初は有用性の科学的評価は 困難である。しかし，10 年単位でみると確実に医療現場 に取り入れられ徐々に標準的な術法に変化していく，産 業界では， disruptive innovation（破壊的革新技術）とし て広く知られた現象であるが，外科特に脳神経外科のわ れわれの領域を例に解説する。次に，手術支援機器の役 割の 1 つである, 可視化に焦点をあて, 可視化から手術 意思決定に役立つインフォ化（情報化）までのプロセス を説明する。そして，可視化によってもたらされた多種 類の情報によって手術中に判断し行動に移すための, い くつかの重要な点を情報ごとに述べる，なお，各情報の 誤差や偽陽性・偽陰性については昨年稿に詳述した ${ }^{15)}$.

今後の展望として, 個々の術中判断のプロセスをフ ローチャート化すること, 手術結果をフィードバックし データベース化することの 2 点によって, 意思決定自体 をナビゲーションできるシステムの構築をあげた。解決 すべき課題は多いが，低りスク高効果の手術あるいは治 療を達成できると考えられ，その基本コンセプトを解説 する。

\section{Disruptive Innovation (破壊的イノベーション)}

症例選択に始まり皮切から閉頭そして術後管理に至る まで，外科医は手術の成功確率を上げるため，技術鍛錬 や経験をフィードバックすることによって，日々改善を 行っている. step by step で持続的な改良作業であり，外 科医の臨床業務において根幹をなすものである。たとえ ば，新しい手術アプローチの開発やマイクロ鋏の形状, あるいはくつつかない双極凝固鑷子の開発などである. 産業界においても，同様に主流市場の従来の価値基準の もとで性能を向上させる新技術を持続的技術 (sustaining technology）といい，一般の企業活動が顧客確保のため
に日常行っている活動であり，たとえば製品の高性能 化，あるいは軽量化や小型化等があたり，想定内の変化 innovation が発生する (Fig. 1).

一方， disruptive technology（破壊的技術）とは，従来 の価值判断の下ではむしろ性能を低下させるが，新しい 価值基準の下では従来製品より優れた特徴を持つ新技術 のことである2．また，破壊的技術がもたらす変化を disruptive innovation（破壊的イノベーション，破壊的技 術革新) という。1995 年に Clayton M. Christensen らが, 提唱した概念であり，古くは馬に対する自動車，銀塩力 メラに対するデジタルカメラ，固定電話に対する携帯電 話等多数の実例がある. 往々にして disruptive technology は簡便で使い勝手がよいために，初心者用として位置づ けられるが，時間とともに従来技術に置き換わり，完全 に代替することも多い。

脳神経外科領域においても, 肉眼的手術に対する顕微 鏡手術，神経学的所見に対する CT/MRI，脳動脈瘤ク リッピングに対するコイリング，そして一般手術に対す るナビゲーションを用いた手術等の実例がある。これら disruptive technologyのどれもが, 臨床現場に登場した当 初はいまだ発展途上であるため，すでに洗練され向上し た従来技術と比較すると，性能が明らかに劣っている. したがって，従来技術の熟練者（領域の重鎮）の評価は 得られず，また科学的な比較試験が行われると優越性を 示せないことが多い．特にその技術が治療を行わない間 接的な手術支援機器は有用性の評価は困難であり，その 例として手術用顕微鏡が有用であるという比較試験の結 果はない。また，手術ナビゲーションの有無に対するラ ンダム化試験（n=45）が造影脳内病変対象に行われた が，ナビゲーション手術群 $(\mathrm{n}=22)$ が通常手術群 $(\mathrm{n}=$ 23）と比較して，摘出率に有意差がない一方で準備時間 が長く生存率が短いという結果であった ${ }^{29)}$.サンプルサ イズが少なく生存率はナビゲーションの評価項目とした という試験デザイン上の欠点はあるが，摘出率で差が示 せなかったことは執刀医がナビゲーションなしで十分高 い技術を擁していた可能性が高い。一方，一回でもナビ ゲーション使用を経験した場合，熟練医であってもその 有用性を疑うものは少ないという事実から，間接的な手 術支援機器の新技術効果を示すことが困難である実例で ある。

当初発展途上であった disruptive technology は，その 中で持続的技術進歩を遂げて，ついには従来技術を超え

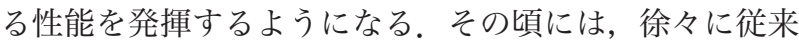
技術に置き換わり，標準技術として新たな市場を形成す る。たとえばナビゲーションでは，赤外線使用やレジス 


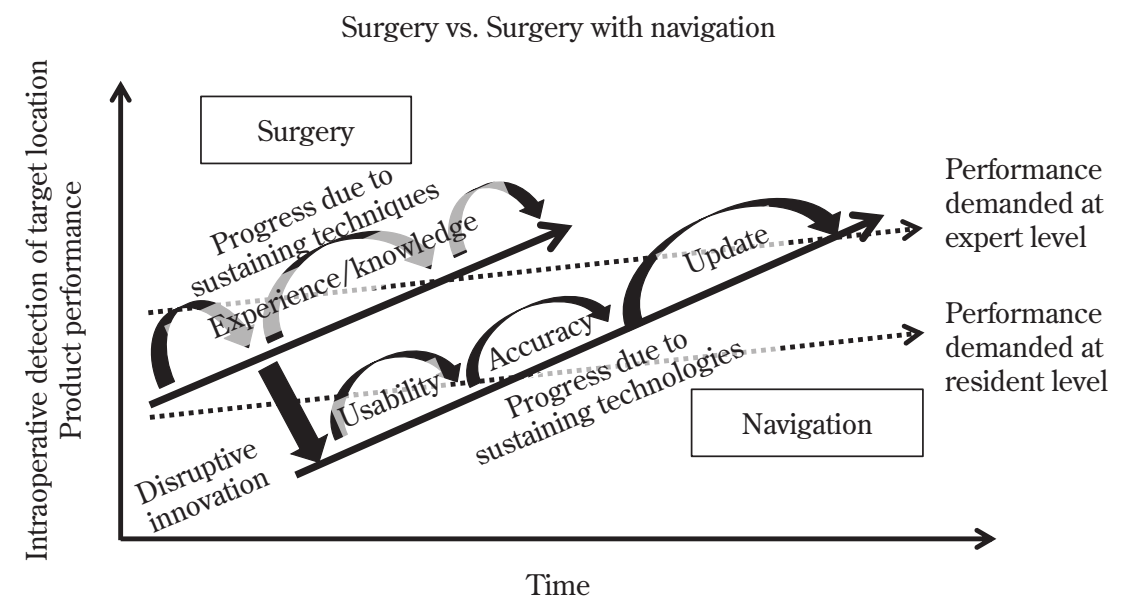

Fig. 1 Performance of the innovative technique in neurosurgery ${ }^{2)}$

Surgical neuronavigation is an example of the relatively novel device for computer-aided intraoperative detection of the target location, as compared with conventional localization technique based on the surgical experience and knowledge of anatomy. At the initial stage of device introduction it performed worse than conventional technique due to wide practical knowledge of the senior surgeons, immature technology of neuronavigation, and use of the novel device by the junior colleagues with limited clinical experience. Nevertheless, later on neuronavigation definitely outperformed conventional localization technique due to technological advances providing improved usability, greater accuracy, and utilization of the real-time information obtained with intraoperative MRI. Due to this progress, since recently intraoperative neuronavigation has considered by experts as a standard technique for brain tumor surgery.

トレーション方式改善による精度向上，そして術中 MRI によるアップデートナビゲーションによるブレインシフ 卜誤差軽減等の技術進歩によって, 熟練医の要求に耐え 得る性能を発揮できるまでとなり, 保険収載もされ標準 術式の 1 つなつた（Fig. 1)。直接の治療法であるコイ ル塞栓術に関しても, 治療医の技術進歩やコイル自体の 機器性能向上そして flow diverter 等新デバイス開発に よって, クリッピングから徐々に適応が置き換わる部位 や施設が増加すると考える。議論はあるが，コイルが優 位性を示す報告も出てきている ${ }^{12)}$. 今回紹介する術中支 援機器のいくつかも, disruptive technology として将来手 術の標準的技術となり得るものである.

\section{術中支援機器による可視化から 情報化まで（Fig. 2)}

従来の手術では術者が五感を研ぎ澄まし術野から生体 情報を取得しているが, 経験差によるゆらぎが大きく, 定性的であるため他のスタッフとの情報共有も容易でな い. 手術支援機器によって生体情報を画像によって可視 化することが解決策であり, 客観的評価や情報共有が容
易となる。術中超音波や MRI 装置, インドシアニング リーンや 5 アミノレブリン酸 (5ALA) 投与後の蛍光観察 装置等がある。また，腫瘍や癌関連の手術では，腫瘍や その近傍のサンプルを採取し可視化することも重要であ り，術中迅速組織診断が代表例である.

可視化された生体信号自体によって客観性のある術中 判断を行えるが，より再現性高い判断を行うためには生 体信号の “意味付けされたデジタルデータ”への変換が 必要である。画像については領域抽出(分画化 segmentation）による関心領域の指定がそれにあたり，定量化そ して多数例の統計学的解析を行うためには必須のステッ プである。

このデジタルデータを参考に術中判断を行い，その術 後結果やゴールド・スタンダード（標準的検査法）との 比較結果をフィードバックすることで，精度向上を図 る。具体的には，測定誤差を計測し低減法を開発する， 偽陽性や偽陰性の事例や頻度を検討し発生頻度を低減す る検査閾值を設定する，である。そして，術者が許容で きる精度となって初めて，意思決定に必要なデー夕すな わち情報となる(インフォ化 $)^{15)}$ 。この生体信号の(1)可視 化，(2)デジタルデータ化，(3)インフォ化（情報化）とい 


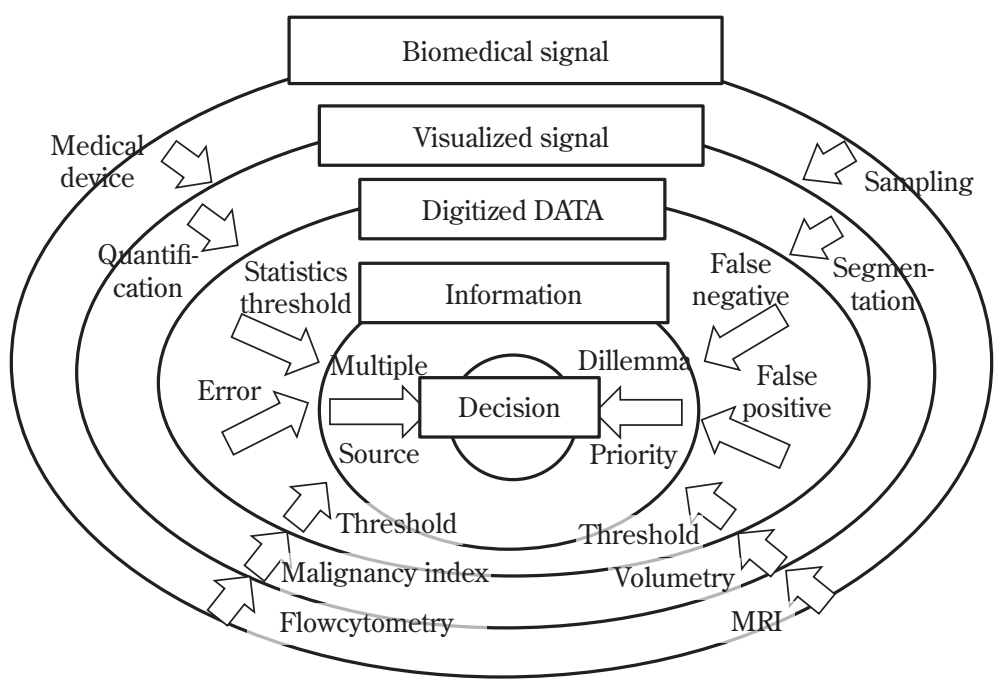

Fig. 2 Scheme of the process of the intraoperative clinical decision-making ${ }^{15)}$

Visualization of the biomedical signals with CT and MRI was a cornerstone for dramatic development of the modern diagnostic medicine. For objective evaluation of the visualized signals it should be transformed into quantitative digital data using various image analyzers and/or computer software. The simple and random digitalized data should be further converted into objective anatomical, functional, and histopathological information. For its effective use during surgical guidance the processing should minimize the errors caused by false negative and false positive results. Various thresholds (resection rate, stimulation current, malignancy index of the tissue specimen etc.) should be considered as possible guidelines for surgical actions with consideration of details of the individual case. Final decision-making of the individual clinician should be based on the integrated information obtained from the multiple sources, which concordance would increase the strength of the clinical solutions, while the conflict of data would demand the probabilistic approach with resolutions of dilemmas through selection of priorities. Lower left: an example of the intraoperative flow cytometry. This technique provides rapid analysis of the DNA content within the sampled cells, and these data may be presented objectively as malignancy index for which threshold for differentiation of the neoplastic and normal tissue may be established and used for surgical decision-making. Lower right: an example of the extent of resection. Volumetric analysis based on the pre- and post-operative MRI may be used for establishment of the optimal threshold for prediction of survival benefits or effects of the adjunctive therapy.

う一連のプロセスは医学によって通常行われている営み であるが，術中は可視化のための検査に関する時間と空 間の制約がきわめて強く，検査を下にした判断が治療 （手術）結果に対する影響が大きいことが特徴である.

3 ステップの実例を，われわれが開発した術中迅速 flowcytometry (以下 FC) 法で述べる (Fig. 3 $)^{22)}$ 。痤攣発 症の 32 歳で術前低悪性度神経膠腫と皮質形成異常を疑 う左海馬病変を有する症例であった (Fig. 3A)。術中 MRI のナビゲーション下で病変中央部サンプリングによる術 中迅速組織診断は，正常ではないが腫瘍と断言できない との報告であった（Fig. 3B）。同時に行った FCでは, 対 照（周辺脳）と比較し明らかな増殖期細胞集団を認めた ため（Fig. 3B），画像上の全摘を行った。2 週後の確定組 織診断はびまん性星細胞腫であり, FCによる組織 DNA
量測定が，適切な手術意思決定につながつた (可視化). 次に, FC の波形デー夕を単数デジタルデータとするた めに, 悪性化指数（増殖期細胞数 $\div$ 全細胞数の \% : malignancy index, MI）という新たな評価基準を設けた（デジ 夕ル化：Fig. 3C)。症例では腫瘍組織は $40 \%$ で周辺脳は $4 \%$ と明確な差となる。この連続変数となったデジタル デー夕によって統計学的検討を行った。神経膠腫手術時 採取した 328 サンプルを用い, FC の MI を確定組織診断 と比較したところ, 腫瘍組織と周辺脳の平均 MI はそれ ぞれ $25.3 \%$ と $4.6 \%$ と有意差を認めた（Fig. 3D）。偽陽性 や偽陰性を最も低減する閾值は ROC 解析によって MI $7 \%$ と示され，MI デー夕が意思決定に有用な情報に変換 可能となった（インフォ化 Fig. 3E)。例えば, MI 10\%と いう結果が出た場合, 閾值同定前は $10 \%$ が単なるデジ夕 


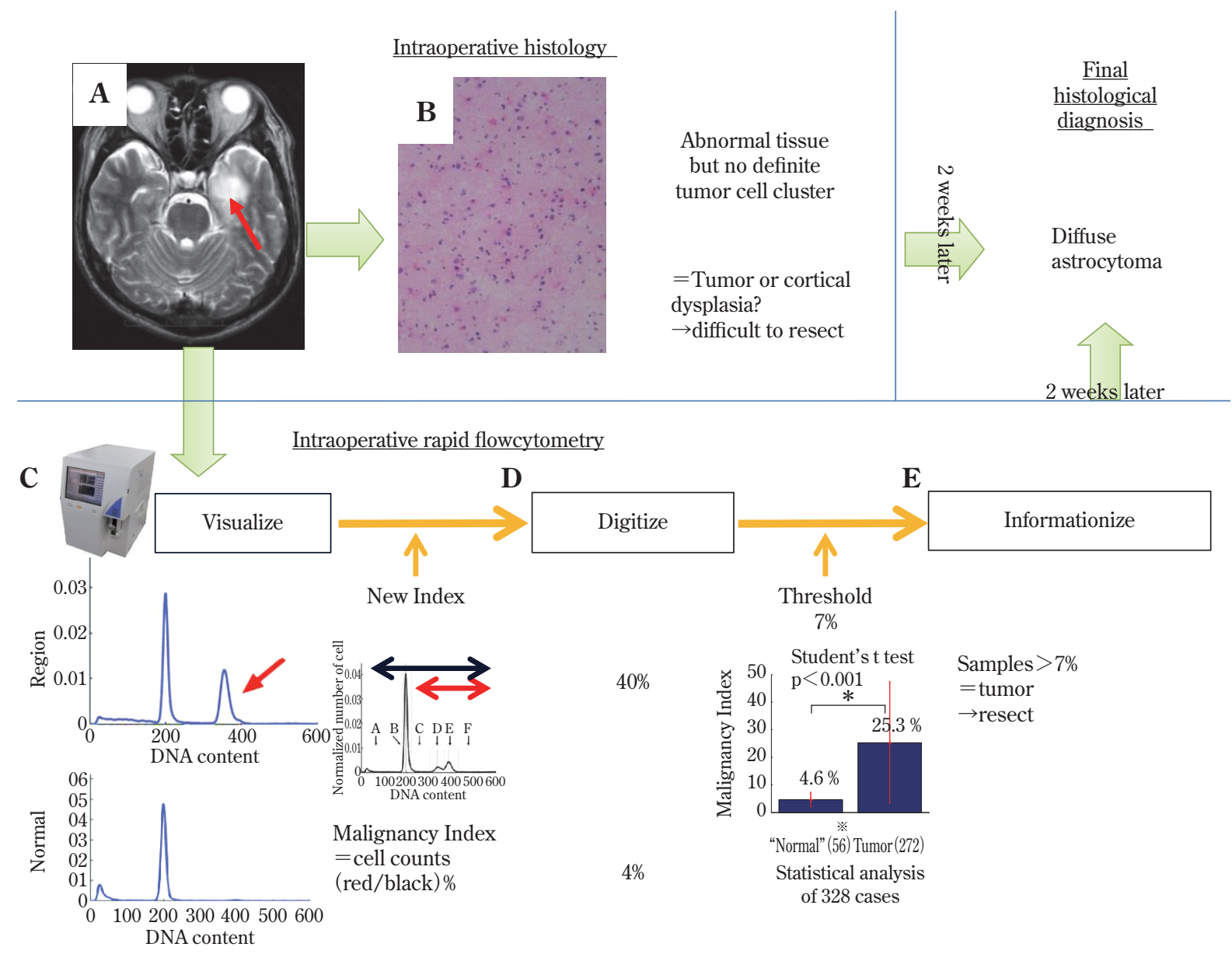

Fig. 3 Processing from visualization to informatization with the new medical device ${ }^{22)}$

A : In a 32-year-old man with epilepsy preoperative T2-weighted MRI showed area of hyperintense signal (arrow) in the left hippocampus, which could be either glioma or a cortical dysplasia.

B : Intraoperative histopathological investigation of the tissue specimen obtained from the center of the lesion did not reveal neoplastic pathology.

C : Novel device for rapid intraoperative flowcytometry clearly demonstrated aneuploid cells (arrow), which led to strong suspicion on the tumor presence and resulted in resection of the lesion; the diagnosis of diffuse astrocytoma was confirmed on the permanent tissue sections 2 weeks after surgery.

D : To digitalize the data obtained with DNA histogram the Malignancy Index, reflecting the relative number of dividing cells within the tissue specimen, was defined.

E : For informatization of these data, 328 different tumor specimens were analyzed and threshold of Malignancy Index for differentiation of the neoplastic and normal tissue was defined statistically at $7 \%$, which can be easily used for intraoperative decision-making during tumor resection.

ルデータであり正常なのか腫瘍なのかの判断困難である が，閾值同定後は MI 10\%がインフォ化により腫瘍と判 断され，摘出意思決定に利用可能となった.

\section{術中判断と行動}

術中支援機器によって得られた各種の“情報”一可視 化，デジタルデータ化，インフォ化さまざまな段階にあ る一は，時系列あるいは集積後に術中判断の元となり， 術者の手術における行動に変換される。神経膠腫の摘出
術では, 解剖学的（構造的）情報・機能的情報・組織学 的情報が意思決定に重要であり，これら術中情報によっ て術中判断し行動する手術を情報誘導手術と呼んでい $ろ^{14)}$.

3 種情報取得の目的は, 機能的情報は機能神経組織の 位置 (マッピング) と状態（温存か否かのモニタリング） の確認, 組織学的情報は腫瘍組織の位置と状態確認であ り, 解剖学的情報は, 腫瘍組織と機能組織の両者に関す る間接的な位置確認である。間接的との意味は, 腫瘍組 織を MRIの異常領域（グレードにより異なる）で代用 
し, 機能組織を MRI 上の古典的な機能野や神経線維の位 置（たとえば中心前回や下前頭回）で代用しているから である。

そして 3 種情報間の優先順位は，機能的情報が最も上 位にあり, 解剖学的情報と組織学的情報はその下位にあ る。機能的情報で示される機能組織が，摘出範囲の限界 を定める制限要素である，具体的には，機能的情報が重 要な脳組織がない non eloquent area であることを示せば 術中 MRI やナビゲーション等の解剖学的情報によって 確実に画像上全摘出可能であり, また術中迅速診断等で 断端に腫瘍細胞塊を認めなければ “組織学的全摘”とな る。一方で, 機能的情報が, 腫瘍内に真の機能組織 eloquent areaがあることを示した場合, 原則摘出できず部 分摘出となる.

これらの情報は積極的摘出の際の意思決定に重要な判 断要素であるため, 各情報ごとに要点を述べる. 解剖学 的情報では, 意味のある一生存期間延長に寄与する一積 極的摘出の目標とすべき摘出率について述べる。機能的 情報では，マッピングやモニタリング検査における偽陽 性（機能組織でないのに症状出現）や現状の言語関連線 維での知見を述べる。組織学的情報では, 迅速免疫染色 等の新規術中迅速診断法について述べる.

\section{1 解剖学的情報 一目標としての摘出閾値一}

手術全体の方針決定に関わる重要な情報を提供する。 術中 MRI や術中 MRIがない場合のナビゲーションから の推察で残存腫瘍がある場合に, どこまで積極的に摘出 するかの判断には, 腫瘍摘出の目標設定が必要である. 摘出目標として, 生存期間に関連する摘出率一生存期間 が延長する摘出率閾值一が論理的である。神経膠腫は浸 潤性であるがゆえに摘出と生存期間との関連は長年疑問 視されてきたが，摘出率閾值という概念を持ち込むこと で科学的な議論となった。

2001 年 Sawaya らのグループから発表されたこのエ ポックメイキングな研究は, 実は分画化, デジタル化と インフォ化の手法を用いている. 術前後の MRIによる体 積測定（volumetry）を用いた正確な測定方法で生存期間 との関連を示した。膠芽腫 $(n=416)$ において造影領域 を腫瘍と定義する（分画化）大胆な方法論一造影周囲に も腫瘍浸潤しているのにかかわらず一で，摘出率を算出 し(デジタルデータ化)，98\%以上と未満とで生存期間に 有意差があると報告した ${ }^{9)}$. $98 \%$ 以上が摘出間值である ことが示唆され（インフォ化）積極的な摘出の理論的根 拠となる一方で，98\%以上の摘出が見込めない症例では 生検という二律背反的な治療方針 (all or nothing strat- egy）とする極端な解釈を行う施設もあり，問題点として 挙げられていた。

そこで，2011 年には Berger らのグループが，膠芽腫 $(\mathrm{n}=500)$ に対し同様の手法で $78 \%$ 以上でも $78 \%$ 未満と 比較し有意差があることを示し ${ }^{21)}, 8$ 割程度摘出の見込 みがあれば開頭術という一般臨床感覚に合致する方針に 論拠を与えた。ちなみに, Berger らも摘出率向上ととも に段階的に生存期間が延長し，かつ全摘群（95\%以上摘 出）が最も予後がよいことを示しており，積極的摘出が 重要でかつ造影領域の全摘に近い摘出が目標であるとい う両者の主張は矛盾しない. 2015 年再び Sawaya らが, 再び膠芽腫 $(n=1,229)$ で FLAIR high 領域の $53 \%$ 以上摘 出が予後と関連しているという発表し，今後議論を呼ぶ と考えられる ${ }^{10)}$.

低悪性度神経膠腫に関しても，2011 年 Bergerらが FLAIR high で $90 \%$ 以上の摘出が予後と関連していると 報告した $(\mathrm{n}=216)^{23)}$ ．2013 年東京女子医科大学の解析 $(\mathrm{n}=147)$ でも同様の $90 \%$ が閾值であり，星細胞腫系は 摘出率と生存期間との関連を認め ${ }^{17)}$ ， より積極的な摘出 を目指すべきとの治療方針を策定した ${ }^{16)}$ 。一方，関連を 認めなかった乏突起系であるが，Sanai らの報告では乏 突起細胞腫でも $(\mathrm{n}=93)$ 摘出率と予後との関連を認めた と報告されており ${ }^{24)}$, 結果の違いはフォローアップ期間 の違いによる可能性もあり，超長期予後を考えた場合積 極的な摘出を目指すべきかもしれない.

術中 MRI 等の術中画像装置を用いると明確に残存腫 瘍が描出されるために, 追加摘出の判断を迫られる。残 存腫瘍部分は，術者が何らかの形でリスクを感じて攻め なかった部分に存在していることが多く，安易な判断は できない，その際に，摘出閾值を目標にし，機能組織の 有無を要素に検討することになる，たとえば星細胞系が 疑われて，いまだ 8 割程度の摘出段階であり，かつ皮質 下マッピングで明確な陽性反応が出ない場合は摘出とな る.

\section{2 機能的情報 一negative mapping technique と positive mapping technique-}

摘出の促進要素であるとともに制限要素である。すな わち, 解剖学的に摘出不能と考える機能野あるいは機能 神経であっても, 覚醒下マッピングや MEP モニタリン グで反応がなければ摘出可能となり (促進), 術中 MRI 等で残存腫瘍があっても反応があれば摘出不可となる (制限)，摘出に最も影響する情報である。また，偽陽性 や偽陰性が起こりやすい情報であるため，起こさない技 術とそれを見抜く適切な術中判断が, 重要となる。また, 
重要な神経組織の損傷を防ぐためには, 一定の安全域を 設ける必要があることも, 摘出範囲の決定を困難にして いる.

偽陽性は，覚醒下手術のマッピングで反応ありあるい はモニタリングで症状出現したがその部位は重要な脳組 織ではない，すなわちその部位は検査で“陽性”だが， 実は摘出による術後欠損症状は起こす部位ではない場合 を示す，偽陽性の原因は，覚醒不良が最も多く，不適切 な麻酔薬使用（言語症例では覚醒後局所麻酔薬以外使用 しない）や長時間の覚醒時間（後半は前半に比べ一般に 覚醒不良）がその原因である。不適切な夕スク（若者に リヤカーの絵をみせても答えられない）や複雑なタスク (覚醒時にも回答が困難) 等の夕スク関連も多く, 脳へラ 等の圧迫での症状出現のこともある ${ }^{11)}$. これら技術的な 偽陽性のみならず，摘出の本質に関わる 2 種類の偽陽性 の議論がある.1つはマッピングにおける電気刺激強度 の閾值であり，もう1つは機能的情報と外科摘出による 欠損症状との関係に起因する根本的なものである.

刺激強度の閾值に関する議論は，マッピングの根本方 針に関するものである。2008 年 Berger らが，長期間多 数例の解析から, 一定の刺激条件 $(60 \mathrm{~Hz}, 6 \mathrm{~mA})$ で言

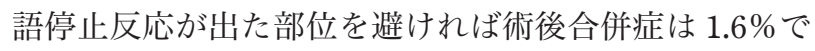
あったと発表した ${ }^{20)}$.すなわち, 一定の刺激条件で反応 がなければ摘出可能である，という negative mapping technique (NMT) の提案であった。その刺激条件より強 い電流で反応が出る部位は摘出可能である，という意味 であり, 刺激条件に閾值がありより強い条件での反応は 偽陽性であるというインフォ化に関する新事実であった。

一方で，刺激条件にかかわらずできる限り機能組織を マッピングしようという，いわば positive mapping technique (PMT) が従来主流であり,われわれは現在もこの 方法を用いている ${ }^{19)}$ ．基礎実験で positive control を置く のと同様に，陽性部位を同定しマッピングシステムの動 作確認ができることと, 偽陰性（実際は重要な脳組織が あるのに同定できない) のリスクを低減できることであ る。

たとえば PMT で言語野を同定してからの摘出であれ ば，言語野を認識できるため避けての摘出は困難ではな い. 一方, NMT で言語野を同定できない場合, 摘出中は 常に隠れた言語野の損傷を懸念しなければいけない。 ま た，マッピングに習熟していない施設が NMT を用いれ ば言語野を見逃す可能性も高く予想外の損傷のリスクが ある。逆にPMTで同定された言語野は偽陽性（たとえ ば $10 \mathrm{~mA}$ で同定）の可能性があり, 過小摘出の可能性を 持つことを認識すべきである。
マッピングの平均反応閾値は, 運動野で $8 \mathrm{~mA}$, 前頭葉 言語野は $9 \mathrm{~mA}$, 頭頂葉/側頭葉言語野では $12 \mathrm{~mA}$ との報 告がある ${ }^{18)}$. $50 \mathrm{~Hz}$ と刺激周波数が異なるため単純には 比較できないが, $6 \mathrm{~mA}$ を閾值とする NMT $(60 \mathrm{~Hz})$ では 言語野は同定できない可能性が高い。実際, Berger らの 言語野同定率は $56 \%$ であり，Duffau らのほぼ $100 \%$ そし て女子医大の $83 \%$ に比べ大幅に下回っている。われわれ は, PMTにおいても言語野を同定できない症例 $(17 \%=$ 100\%-83\%）の特徵として, 腫瘍が前頭葉三角部に存在 することを見出した ${ }^{19)}$.

したがって, PMT を基本に機能野（候補）をできる限 り同定し, そこを避けて摘出を行う。もし, 腫瘍内に機 能野候補が共存しており，それが $10 \mathrm{~mA}$ 以上の刺激で同 定した機能野である場合は摘出を検討するといった， PMT と NMT を組み合わせた摘出方法がよいと考える。

言語線維に関しては，電流閾值とともに，わ的われは 部位としての偽陽性の可能性を主張している。言い換え れば，刺激による言語停止や摘出中に出現した言語症状 が検査上真の陽性であっても，外科的には摘出可能な場 合があると考えている，優位半球脳室前角の外側，側頭 葉前方深部白質等の部位である。それぞれ，梁下束，鉤 状束が関連すると考えられるが，古典的な脳神経外科学 では摘出によって明らかな永続的な言語障害を認めない 部位である。電気刺激が伝導したための症状が出現し た，あるいは当該線維が側副言語神経路であり障害に よっても症状が顕在化しにくい，等の理由が考えられ る，後者である場合に，保存すべき本質的な言語線維は ぞれかという疑問が生じる。

われわれは，神経膠腫患者に対して文法タスクを用い た fMRI を施行し，14 の文法関連皮質を同定し相関解析 により 3 グループに分か水ること，そして 3 グループ内 の皮質は tractographyによって接続していること，を発 見した (Fig. 4). 古典的な言語線維であり近年背側ネッ トワークと命名された弓状束/上縦束は小脳虫部の線維 を含めたグループII を形成（文法と出入力インターフェ イス)，近年腹側ネットワークとして注目を浴びる下前 頭後頭束はグループIII (文法と意味処理)，そして左前頭 葉弁蓋部/三角部から脳梁を介し右前頭葉弁蓋部/三角部 そして右 preSMA と右頭頂葉と左頭頂葉からなり右半球 が関わる新規のグループ I（文法と補助システム）から なる.

前述の梁下束や鉤状束は 3 文法ネットワークに属して おらず，かつ古典的な前頭葉と側頭葉 lobectomy の切除 範囲内の線維であること, すなわち MRI 科学的にも外科 学的なビックデータからもマッピング/モニタリング上 

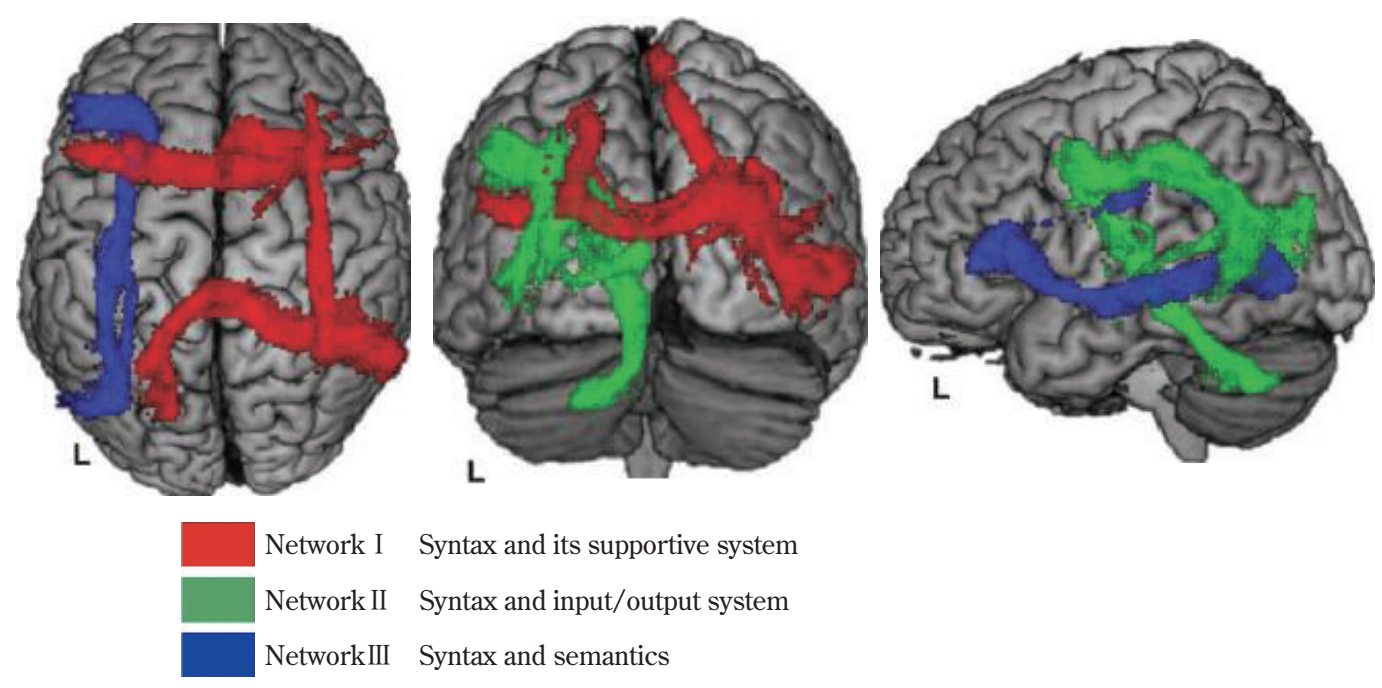

Fig. 4 Three syntax-related networks ${ }^{8)}$

Brain activity analysis in glioma patients with syntax disorders revealed 3 related neuronal networks. Network I (red) includes opercular/triangular parts of the left inferior frontal gyrus, left intraparietal sulcus, right frontal regions, pre-supplementary motor area, and right temporal regions (syntax and its supportive system). Network II (green) includes left lateral premotor cortex, left angular gyrus, lingual gyrus, and cerebellar nuclei (syntax and input/output system). Network III (blue) includes left ventral frontal and posterior temporal regions (syntax and semantics).

で真の陽性だとしても切除可能な可能性が高い. 今後, 言語を含めた高次脳機能のマッピング/モニタリングは 進化していくと考えられるが，マッピング/モニタリン グ検査上での陽性と外科的摘出に関しての陽性（切除不 能な重要組織）とは異なる可能性があること，神経膠腫 は生命予後に関わる疾患で摘出が大きな予後因子である こと，を念頭に術中判断と摘出行動を決定すべきと思わ れる。

機能的情報は，摘出に関して促進要素でもあり制限要 素でもある。どちらの作用が強いかを示唆するメ夕解析 （n=8,091）の報告があり, マッピングあり群で画像上の 全摘出症例割合が $75 \%$ と，マッピングなし群の $55 \%$ と 比較して有意に高かった ${ }^{5)}$. 機能的情報が摘出に関して 促進作用が強いとの結果であるが，加えて晚期重篤術後 合併症もマッピングあり群が $3.4 \%$ で，なし群が $8.2 \%$ と 本来の神経温存も達成できている，生命予後に関して も，延長効果を示唆する報告がある $(n=281)$. 画像上 eloquent area に腫瘍が存在してもマッピングで eloquent でないことが確認できた群は, non eloquent areaに腫瘍 が存在した群と同等の予後であり，マッピングで eloquent area であった群あるいはマッピングなし群と比較 して，予後良好であった，といゔ”。 みかけ上の eloquent をマッピングで non eloquent と確認でき，摘出度が上 がったと推察される。したがって，機能的情報による予
後改善を目指すためには，みかけ上の eloquent 症例にで きる限り覚醒下マッピング/モニタリングを行うべきで ある。そのためには, “pseudo-eloquent” area であるこ とを確認できる精度の高いマッピング/モニタリングの 技術が必要となる。

将来的には，永続的な欠損症状を起こし得る部位のリ スクマップを作成し，より成功確率の高い摘出を可能に する。すなわちリスク領域外は通常摘出し，リスク領域 には高次脳機能を含めた精緻なマッピング/モニタリン グを行い，患者の社会的要求にも応え得る最大限の摘出 が可能になると考える。

\section{3 組織学的情報}

\section{一 sampling error と術中迅速検查法一}

術中迅速組織診断は組織学的情報の中で最も信頼でき る方法であるが，きわめて小さな範囲のサンプリングで あり, 判定までの 15〜30 分程度の時間を要すること等 の，問題点がある，病理医にとっても，永久標本と異な る凍結あるいは smear 等の組織固定，そして HE 染色の みの標本しか材料がなく，かつ短時間で外科医に報告し なければならないといった条件から，判断は容易ではな い.したがって，“周辺でありより腫瘍側のサンプルを提 出してほしい” あるいは“正常ではないが腫瘍とも断定 できない”等の回答も少なくない. 
神経膠腫を疑う症例において，生検による組織診断の “正答率”を, MRS ガイドで生検術を施行後に摘出術を 施行した症例 $(n=26)$ で検討した研究がある（深部電極 を埋め込む際に生検を行い, 深部電極による白質マッピ ング後摘出を行っていた時期がある $)^{4) 11}$. 神経膠腫と診 断できた症例が $88 \%$, 神経膠腫のサブタイプまで診断で きた症例の割合が $77 \%$, サブタイプと WHO grade まで

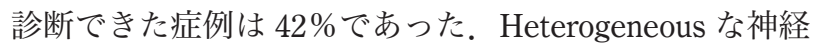
膠腫を一部の組織で診断することの困難さ，言い換えれ ばサンプリングエラーが起こる可能性が高く, エラーを 常に意識しての術中判断が必要である.

術中迅速診断の結果によって手術方針が大きく変わる 場合が，悪性神経膠腫と悪性リンパ腫との鑑別である. 前者は積極的摘出を目指し後者は診断可能な小さな組織 取得（生検）で手術は終了する。その鑑別は，血中マー カー, そしてMRI の拡散強調画像（DWI）や Tl SPECT あるいは FDG-PET ${ }^{30}$ 等の画像で術前に容易にできると 考えられている。しかし， DWI で低吸収のリンパ腫，T1 SPECTで hot な退形成性星細胞腫も経験しており, 実臨 床レベルでは術前診断と術中診断が異なる場合を常に想 定して, 患者へのインフォームドコンセントや手術計画 変更を計画しておくべきである，特に腎移植後は，移植 後リンパ増殖性疾患（PTLD）という病態も認識すべき である。さらに，術中迅速診断においても細胞密度が高 い両者の鑑別は容易ではなく, 近年開発された迅速免疫 染色法 ${ }^{27)}$ による抗 CD20 抗体染色が鑑別にきわめて有用 な方法である。この術中迅速免疫染色や前述の術中flowcytometry 法を含め, ルーチンの術後組織学的検查を短 時間化して術中判断に役立てようとする試みが近年盛ん である. IDH 変異の術中迅速 $\mathrm{PCR}^{6}$ も実用化レベルであ り，今後さらに発展していく分野だと考える.

小範囲のサンプリングという術中組織診断を解決する のが，5ALA による術中蛍光診断（光線力学的診断）で ある7 ${ }^{725)}$. 術野全体の中で腫瘍の位置をリアルタイムに 可視化できる優れた方法である。膠芽腫ではきわめて有 用であるが，低悪性度神経膠腫での有用性は認められて いない28)，通常は，顕微鏡下あるいは肉眼で観察し，蛍 光が観察される部分を強陽性, 弱陽性, 陰性とおよそ判 断し陽性部分の摘出を行う。弱陽性と陰性の判断は時に 容易ではないため, 光学的に測定し定量化 ${ }^{1)}$ ・デジタル 化を行う手法が開発されている。閾值以上のシグナル時 に術者に音で知らせる, あるいは吸引器が作動し摘出す る装置も開発されており, インフォ化による自動判断を 利用した技術である。

組織学的情報の展望として, 強力な予後因子である 1p19q loss や IDH1 変異を含めた情報が術中短時間で同 定できる技術の開発がある。たとえば“loss ありは放射 線化学療法の効果が期待できるため摘出を迷った部位は 温存”等の全体の方針に重要な示唆を与える。しかしこ れらは根幹の遺伝子異常であり, どの部位をより摘出す べき，という情報ではない。一方で，神経膠腫は同一腫 瘍内でも遺伝子的にきわめて heterogeneous ${ }^{26)}$ であるた め, 術中迅速に同定できかつ予後に関連する組織学的情 報を，部位ごとに取得できれば摘出意思決定に有用とな る。将来 (予後) を予測し, 悪性転化や再発を起こす部 位を特定するシステム構築が, 組織学的情報に求められ る.

\section{おわりに}

日常を変え得る disruptive innovation について，医療特 に脳神経外科における実例を示すとともに解説した。そ の innovationの 1 つとして手術支援機器による生体情報 の可視化があり,さらに発展させるための方策として, デジタル化，インフォ化のステップを紹介した。これら 可視化された情報を用いて, 成功確率の高い判断と行動 を行うためには，各情報ごとのインフォ化が必要であ る。解剖学的情報では摘出率閾值，機能的情報では刺激 閾值, 組織学的情報では flowcytometry を例に挙げたが, その閾值は絶対值ではなく 1 つの指標であり，施設方針 や患者希望で変更し得る。たとえば，摘出を優先する方 針の組織では摘出率目標は閾值以上となり，機能を優先 する施設では反応ありとする電気刺激の電流閾值は上が る。患者希望も然りである。

今後の展望として, 個々の術中判断のプロセスをつ ローチャート化すること，合併症を含めて手術結果を フィードバックしデータベース化することによって，意 思決定自体をナビゲーションできるシステムの構築が挙 げられる，解決すべき課題は多いが，低りスク高効果の 手術あるいは治療を達成するために有用なシステムと考 えられ, 現在開発を行っている。

\section{謝 辞}

情報誘導手術の機会を与えていただきました高倉公朋先 生, 堀 智勝先生, 久保長生先生に深謝いたします。また, 研究全般を支援いただいた生田聡子先生, 吉光喜太郎先生, 岡本 淳先生, 小西良幸先生, 正宗賢先生, 岡本沙織先生, 中島 温先生に深謝いたします。

著者全員は日本脳神経外科学会への COI 自己申告の登録を 完了しています。本論文に関して開示すべきCOI はありませ h. 


\section{文 献}

1) Ando T, Kobayashi E, Liao H, Maruyama T, Muragaki Y, Iseki $\mathrm{H}$, Kubo O, Sakuma I: Precise comparison of protoporphyrinIX fluorescence spectra with pathological results for brain tumor tissue identification. Brain Tumor Pathol 28: 43-51, 2011.

2) Bower JL, Christensen CM : Disruptive Technologies: Catching the Wave. Harvard Business Review January- February, 1995.

3) Chang EF, Clark A, Smith JS, Polley MY, Chang SM, Barbaro NM, Parsa AT, McDermott MW, Berger MS : Functional mapping-guided resection of low-grade gliomas in eloquent areas of the brain: improvement of long-term survival. Clinical article. J Neurosurg 114: 566-573, 2011.

4) Chernov MF, Muragaki Y, Ochiai T, Taira T, Ono Y, Usukura M, Maruyama T, Nakaya K, Nakamura R, Iseki H, Kubo O, Hori T, Takakura K : Spectroscopy-supported frame-based image-guided stereotactic biopsy of parenchymal brain lesions : comparative evaluation of diagnostic yield and diagnostic accuracy. Clin Neurol Neurosurg 111:527-535, 2009.

5) De Witt Hamer PC, Robles SG, Zwinderman AH, Duffau H, Berger MS : Impact of intraoperative stimulation brain mapping on glioma surgery outcome: a meta-analysis. J Clin Oncol 30:2559-2565, 2012.

6) Kanamori M, Kikuchi A, Watanabe M, Shibahara I, Saito R, Yamashita Y, Sonoda Y, Kumabe T, Kure S, Tominaga T : Rapid and sensitive intraoperative detection of mutations in the isocitrate dehydrogenase 1 and 2 genes during surgery for glioma. J Neurosurg 120: 1288-1297, 2014.

7）金子貞男：悪性脳腫瘍に対する光線力学的療法一光感受 性物質 ALA を用いたPDD と PDTを中心に. 日レ医誌 29: 135-146, 2008.

8) Kinno R, Ohta S, Muragaki Y, Maruyama T, Sakai KL : Differential reorganization of three syntax-related networks induced by a left frontal glioma. Brain 137 : 1193-1212, 2014.

9) Lacroix M, Abi-Said D, Fourney DR, Gokaslan ZL, Shi W, DeMonte F, Lang FF, McCutcheon IE, Hassenbusch SJ, Holland E, Hess K, Michael C, Miller D, Sawaya R: A multivariate analysis of 416 patients with glioblastoma multiforme : prognosis, extent of resection, and survival. $J$ Neurosurg 95: 190-198, 2001.

10) Li YM, Suki D, Hess K, Sawaya R : The influence of maximum safe resection of glioblastoma on survival in 1229 patients : Can we do better than gross-total resection? J Neurosurg 124: 977-988, 2016.

11）丸山隆志, 村垣善浩, 田中雅彦, 堀 智勝: グリオーマ における術中モニタリング。脳 21 12:79-85, 2009.

12) Molyneux AJ, Birks J, Clarke A, Sneade M, Kerr RS: The durability of endovascular coiling versus neurosurgical clipping of ruptured cerebral aneurysms : 18 year follow-up of the UK cohort of the International Subarachnoid Aneurysm Trial (ISAT). Lancet 385:691-697, 2015.

13) Muragaki Y, Chernov M, Maruyama T, Ochiai T, Taira T, Kubo O, Nakamura R, Iseki H, Hori T, Takakura K : Lowgrade glioma on stereotactic biopsy : how often is the diagnosis accurate? Minim Invasive Neurosurg 51:275-279, 2008.

14) Muragaki $Y$, Iseki $H$, Maruyama T, Tanaka M, Shinohara $C$, Suzuki T, Yoshimitsu K, Ikuta S, Hayashi M, Chernov M, Hori T, Okada Y, Takakura K : Information-guided surgical management of gliomas using low-field-strength intraoperative MRI. Acta Neurochir Suppl 109: 67-72, 2011.

15）村垣善浩, 伊関 洋, 丸山隆志, 新田雅之, 齋藤太一, 田村 学, 岡田芳和: 可視化情報を統合する意思決定学. 脳外誌 $23: 876-886,2014$.

16) Nitta M, Muragaki Y, Maruyama T, Ikuta S, Komori T, Maebayashi K, Iseki H, Tamura M, Saito T, Okamoto S, Chernov M, Hayashi M, Okada Y : Proposed therapeutic strategy for adult low-grade glioma based on aggressive tumor resection. Neurosurg Focus $\quad 38:$ E7, 2015.

17) Nitta M, Muragaki $Y$, Maruyama T, Iseki H, Ikuta S, Konishi Y, Saito T, Tamura M, Chernov M, Watanabe A, Okamoto S, Maebayashi K, Mitsuhashi N, Okada Y : Updated therapeutic strategy for adult low-grade glioma stratified by resection and tumor subtype. Neurol Med Chir (Tokyo) $\mathbf{5 3}$ : 447-454, 2013.

18) Pouratian N, Cannestra AF, Bookheimer SY, Martin NA, Toga AW : Variability of intraoperative electrocortical stimulation mapping parameters across and within individuals. $J$ Neurosurg 101: 458-466, 2004.

19) Saito T, Muragaki $Y$, Maruyama T, Tamura M, Nitta M, Tsuzuki S, Konishi Y, Kamata K, Kinno R, Sakai KL, Iseki H, Kawamata $\mathrm{T}$ : Difficulty in identification of the frontal language area in patients with dominant frontal gliomas that involve the pars triangularis. J Neurosurg 22: 1-9, 2016.

20) Sanai N, Mirzadeh Z, Berger MS : Functional outcome after language mapping for glioma resection. $N$ Engl J Med 358: 18-27, 2008.

21) Sanai N, Polley MY, McDermott MW, Parsa AT, Berger MS : An extent of resection threshold for newly diagnosed glioblastomas.J Neurosurg $115: 3-8,2011$.

22) Shioyama T, Muragaki Y, Maruyama T, Komori T, Iseki H : Intraoperative flow cytometry analysis of glioma tissue for rapid determination of tumor presence and its histopathological grade : clinical article. J Neurosurg 118: 12321238, 2013.

23) Smith JS, Chang EF, Lamborn KR, Chang SM, Prados MD, Cha S, Tihan T, Vandenberg S, McDermott MW, Berger MS : Role of extent of resection in the long-term outcome of low-grade hemispheric gliomas. J Clin Oncol $26: 1338^{-}$ $1345,2008$.

24) Snyder LA, Wolf AB, Oppenlander ME, Bina R, Wilson JR, Ashby L, Brachman D, Coons SW, Spetzler RF, Sanai N : The impact of extent of resection on malignant transformation of pure oligodendrogliomas. J Neurosurg $\quad 120: 309$ 314, 2014.

25) Stummer W, Pichlmeier U, Meinel T, Wiestler OD, Zanella F, Reulen HJ : Fluorescence-guided surgery with 5-aminolevulinic acid for resection of malignant glioma : a randomised controlled multicentre phase III trial. Lancet Oncol $\quad 7: 392^{-}$ 401, 2006.

26) Suzuki H, Aoki K, Chiba K, Sato Y, Shiozawa Y, Shiraishi Y, Shimamura T, Niida A, Motomura K, Ohka F, Yamamoto T, Tanahashi K, Ranjit M, Wakabayashi T, Yoshizato T, Kataoka K, Yoshida K, Nagata Y, Sato-Otsubo A, Tanaka H, Sanada M, Kondo Y, Nakamura H, Mizoguchi M, Abe T, Muragaki Y, Watanabe R, Ito I, Miyano S, Natsume A, Ogawa S: Mutational landscape and clonal architecture in grade II and III gliomas. Nat Genet $\quad 47:$ 458-468, 2015.

27) Tanino M, Sasajima T, Nanjo H, Akesaka S, Kagaya M, Kimura T, Ishida Y, Oda M, Takahashi M, Sugawara T, Yoshioka T, Nishihara H, Akagami Y, Goto A, Minamiya Y, Tanaka 
S ; R-IHC Study Group : Rapid immunohistochemistry based on alternating current electric field for intraoperative diagnosis of brain tumors. Brain Tumor Pathol $32: 12-19$, 2015.

28) Valdés PA, Jacobs V, Harris BT, Wilson BC, Leblond F, Paulsen KD, Roberts DW : Quantitative fluorescence using 5-aminolevulinic acid-induced protoporphyrin IX biomarker as a surgical adjunct in low-grade glioma surgery. J Neurosurg 123: 771-780, 2015.

29) Willems PW, Taphoorn MJ, Burger H, Berkelbach van der Sprenkel JW, Tulleken CA : Effectiveness of neuronavigation in resecting solitary intracerebral contrast-enhancing tumors : a randomized controlled trial. J Neurosurg 104 : 360-368, 2006.

30) Yamashita K, Yoshiura T, Hiwatashi A, Togao O, Yoshimoto K, Suzuki SO, Abe K, Kikuchi K, Maruoka Y, Mizoguchi M, Iwaki T, Honda $\mathrm{H}$ : Differentiating primary CNS lymphoma from glioblastoma multiforme : assessment using arterial spin labeling, diffusion-weighted imaging, and (1) (8) Ffluorodeoxyglucose positron emission tomography. Neuroradiology $\mathbf{5 5}:$ 135-143, 2013.

要

手術支援機器による術中判断と行動

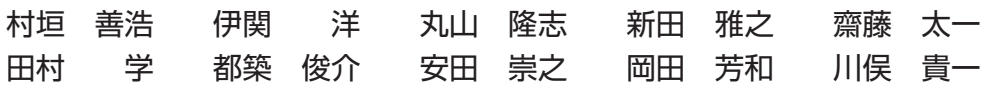

手術において外科医の不断の技術改善や術式開発は持続的 innovation として step by step での成績 向上に寄与している. 一方で distruptive innovation（“破壊的” イノベーション）といわれる非連続的 な変化は, 新規医療機器でもたらされることが多い. CT や MRI, ガンマナイフやコイル等の診断治 療機器, そして手術用顕微鏡やナビゲーション等の手術支援機器である. 今回, 手術支援機器による 情報をどのように術中判断し行動に移すべきかを解説した.

新規手術支援機器の本質的な目的は, 生体情報の可視化である. 可視化された新規画像自体で術中 判断に貢献するが, 多くは定性的であり判断に経験が必要である. 第 2 段階として, 画像解析による 定量化や画像抽出（segmentation）によって意味付けされたデジタルデータへ変換できればより客観 的なデータとなる. 第 3 段階としてデジタル “データ”を意思決定に有用な “情報”に変換する（イ ンフォ化：情報化）が必要となる. インフォ化の具体例として, 解剖学的情報は摘出閾值, 機能的情 報は刺激強度閾値, 組織学的情報は術中 flowcytometry を提示する.

インフォ化された情報は, 意思決定と行動に直結するため, 条件や統計そして環境を理解したうえ で使用すべきである. インフォ化の元になる閾值は絶対的なものでなくあくまで指標であり, 施設方 針や患者希望で変え得る. 多施設でのフィードバックにより, より成功確率の高い手術支援機器によ る情報のインフォ化を目指すべきと考える. 